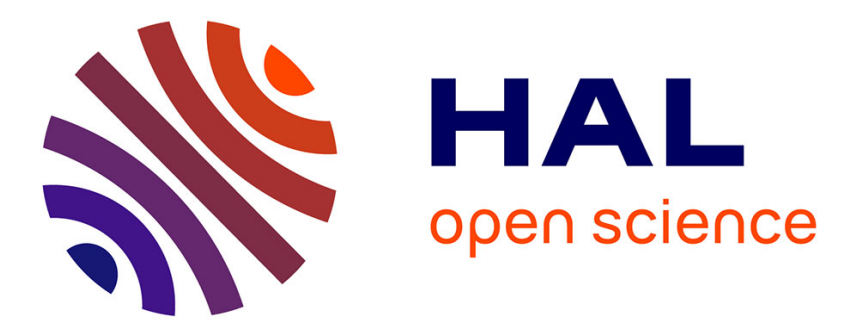

\title{
Biomass fast pyrolysis: Chemistry and thermodynamics
}

Marion Carrier, Manel Nasfi, Malek Ajam, Laurent Cassayre, Sylvain Salvador

\section{To cite this version:}

Marion Carrier, Manel Nasfi, Malek Ajam, Laurent Cassayre, Sylvain Salvador. Biomass fast pyrolysis: Chemistry and thermodynamics. EGU21 - EGU General Assembly 2021, Apr 2021, Online, Germany. 2 p., 10.5194/egusphere-egu21-2878 . hal-03197332

\section{HAL Id: hal-03197332 https://imt-mines-albi.hal.science/hal-03197332}

Submitted on 13 Apr 2021

HAL is a multi-disciplinary open access archive for the deposit and dissemination of scientific research documents, whether they are published or not. The documents may come from teaching and research institutions in France or abroad, or from public or private research centers.
L'archive ouverte pluridisciplinaire HAL, est destinée au dépôt et à la diffusion de documents scientifiques de niveau recherche, publiés ou non, émanant des établissements d'enseignement et de recherche français ou étrangers, des laboratoires publics ou privés.

\section{(c)(1)}

Distributed under a Creative Commons Attribution| 4.0 International License 


\title{
EGU21-2878
}

https://doi.org/10.5194/egusphere-egu21-2878

EGU General Assembly 2021

(c) Author(s) 2021. This work is distributed under

the Creative Commons Attribution 4.0 License.

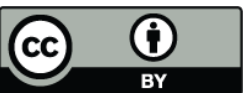

\section{Biomass fast pyrolysis: Chemistry and thermodynamics}

\author{
Marion Carrier ${ }^{1}$, Manel Nasfi ${ }^{1}$, Malek Ajam ${ }^{1}$, Laurent Cassayre ${ }^{2}$, and Sylvain Salvador ${ }^{1}$ \\ ${ }^{1}$ RAPSODEE, Université of Toulouse, CNRS, IMT Mines Albi, France (marion.carrier@mines-albi.fr) \\ ${ }^{2}$ Laboratoire de Génie Chimique, Université of Toulouse, CNRS, INPT, UPS, Toulouse, France
}

The project, PYROKINE, aims at developing new modeling approaches adapted to one of the most promising thermochemical processes, fast pyrolysis, applied to the conversion of contaminated lignocellulosic biomass. The fast pyrolysis converts solid biomass into volatiles and a limited amount of char. The volatiles are then rapidly quenched resulting in a high yield of bio-oil, $70-75 \mathrm{wt} \%$ of the starting material on a dry basis. The liquified biomass can be further upgraded catalytically or blended to produce new advanced biofuels. In addition to the yield, the product distribution determines their quality, and this is critically dependent on biomass type and its temperature-time history. In the present study, we propose to establish a dynamic model adaptable to the conversion of different biomass types under various pyrolysis regimes according to two research programs.

The first program consists of integrating coupled chemical kinetics into heat and mass transfer models for biomass fast pyrolysis. So far, the coupled kinetic model combining the Friedman isoconversional method with a Distributed Activated Energy Model (DAEM) has been developed and validated with a set of experimental data obtained under slow heating conditions. The apparent activation energy, Ea, one of the kinetic parameters that describes the overall reactivity of the feedstock, has been plotted versus the extent of conversion, $a$, to assess the chemical complexity of the reaction. For example, the lignin was found to degrade into two successive stages from 174 to $280 \mathrm{~kJ} / \mathrm{mol}$ between $0.05<\mathrm{a}<0.60$ and up to $322 \mathrm{~kJ} / \mathrm{mol}$ until $\mathrm{a}=0.85$. Two kinetic parameter datasets were derived and used as inputs for the double-Gaussian DAEM that successfully fitted experimental curves. This chemical kinetic model will be combined with heat and mass transport models according to the type of thermal regimes.

The second program focuses on the thermodynamic and kinetic modeling of the intermediate liquid compound in the presence of metallic species. This liquid appears in the early stages of the fast pyrolysis and results from the softening of biomass. Its physico-chemical characteristics are the origin of the multiphasic nature of the biomass fast pyrolysis. A preliminary study has allowed the development of a thermodynamic model and headspace coupled to gas chromatographic methods to predict the vapor-liquid equilibrium for model liquid mixtures. The system studied was a closed system with air and a solution mixture of five components (acetic acid, hydroxyacetone, phenol, furfural, and methanol) near its boiling point, $90^{\circ} \mathrm{C}$, and under atmospheric pressure. To predict the thermophysical parameters of the solution, the Soave-Redlich-Kwong (SRK) equation of state coupled with Modified Huron-Vidal (MHV2) mixing rules incorporating the UNIversal 
Functionnal Activity Coefficient (UNIFAC) model was implemented. Concentration measurements in vapor and liquid phases were compared to vapor-liquid equilibrium data. A quantitative agreement between simulated and measured concentrations in the liquid phase was achieved with this combined state-predictive model of the SRK-MHV2-UNIFAC model, confirming that it accounts well for the nonidealities. This thermodynamic model will need to be coupled with a chemical kinetic model in the presence of inorganics to reveal the role of those contaminants on the chemistry. 